\title{
Talking with Glycoscientists throughout the World via the Internet
}

\author{
The Glycoscience Network で世界中の糖質研究者と会話する
}

\author{
Iida-Tanaka, Naoko ; and Ishizuka, Ineo \\ Department of Biochemistry, Teikyo University School of Medicine, Itabashi-ku, Tokyo, 173-8605, Japan \\ FAX: 81-3-5375-6366, E-mail: ntanaka@med.teikyo-u.ac.jp
}

Key Words : electronic conference, forum, Glycoscience Network, mailing list

\begin{abstract}
This is a brief guide to the Glycoscience Network (TGN), an informal world-wide grouping which shares information related to carbohydrates.

At the present time, we can easily obtain a lot of information on the World Wide Web (WWW) pages. But there may be a lot of people that wish to know which site is useful for carbohydrate studies. Furthermore, some people may use older computers on which WWW browsers such as Netscape and Internet Explorer can not work.

It will be helpful for them to be aware of the mailing list of the glycoscience Network (TGN mailing list). Anyone who can receive and send e-mail is able to obtain lots of information from glycoscientists anywhere in the world through the TGN mailing list. Iain Wilson and Barry Hardy, who set up TGN, explain the history and the purpose of TGN in a paper titled "Glycoscience and the Internet" which was published in TIGG (1996), 8: 301-310. In this paper, we will describe for beginners how to use the TGN mailing list.
\end{abstract}

\section{A. How to Subscribe to the TGN Mailing List}

To subscribe to the TGN list, you should send an e-mail to tgn-request@ vei.co.uk with the following in the body of your e-mail message in which any subject is available:

\section{subscribe tgn}

If the e-mail address you wish to subscribe to is not the address of your e-mail, you should add it to the line:

subscribe tgn @

Please note that mail including usual expressions such as "Dear sir, ....." and "I would like to subscribe ....." in the first line should not be used, because the first word, "subscribe", is automatically recognized as one of the List Manager Commands. When you are successful, you will receive a message titled "Welcome to tgn" within a few minutes.
要 約

糖質研究者がインターネット上で情報を交換するシステ ム、The Glycoscience Network (TGN) をご紹介します。

インターネットにアクセスすると、自分でも意識せずに世 界中の情報サイトを縦横無尽に行き来して、様々な情報を入手 できる時代になってきました。でも、情報が多すぎてどこを見 たらいいのやら、最初はそんな気分になる方も少なくないと思 われます。 Netscape や Internet Explorer など World Wide Webに こぎ出すためのブラウザソフトも古いコンピューターではス ムーズに動かない、ということもあるかもしれません。

The Glycoscience Network (TGN) は、メーリングリストによ るメンバーどうしの情報交換を主体にしたネットワークです。 基本的には、メールの授受が出来れば世界の糖質研究者たちと 情報交換できるシステムです。

TGN の創設メンバーである Iain Wilson と Barry Hardy が、 TIGG (1996), 8 : 301-310の「糖質科学とインターネット」とい う文章の中で TGN の成り立ちについて詳しく紹介していますの で、ここでは、「だれにでもわかる TGN 利用法」をめざして書 かせていただきたいと思います。

\section{A. TGNのメーリングリストに登録する}

tgn-request@vei.co.uk 宛に

subscribe tgn

と一行書いたメールを出します(手紙の表題 (Subject) はなん でもよい)。この時、TGNに登録したい E-mail アドレスが発信 者のアドレスと異なる場合には、

subscribe tgn @

のようにアドレスを記入しておく必要があります。ここで 注意することは、最初の “subscribe” の単語がコマンドとして自 動的に認識されるシステムになっているため、“Dear sir, .....” と か “I would like to subscribe .....” のような普通の手紙スタイルの 文章にしてしまうと拒否されてしまうことです。

ちゃんと登録されれば、数分後には“Welcome to tgn”とい う表題のメールが届くはずです。そしてそれ以後、TGNメーリ ングリスト宛に送られたメールが自動的に転送されることにな ります。 


\section{B. What Kind of E-mail is Available from the TGN List?}

An example of mail is as follows: (Fig. 1)
B. TGNでやりとりされているメールってどんなもの? メールをいくつかご紹介しましょう。(図1)

Fig. 1.

I would like to know if any possibility exists to differentiate a high mannose oligosaccharide of a hybrid type.

Does there exist any endoglycosidase which selectively cleaves oligosaccharides of the oligomannose type but doesn't work on oligosaccharides of the hybrid type? Any suggestions would be appreciated.

Thank you very much.

A reply to the above mail is: (Fig. 2) このメールに対する返事は (図2)

Fig. 2.

You could use alpha-mannosidase to cleave the mannose branch while keeping the complex branch intact.

You can ask questions to people you have never met, and receive answers from them via TGN. If you have no adviser at your place of work, you will understand how useful this could be.

Recently, there has been an increase in mail about postdoctoral positions (Fig. 3).

このように、実験上での疑問について、まったく面識のな い人から情報をもらうことができます。まわりに質問できる人 がいない環境では、そのありがたさは筆舌に尽くしがたいとい うところでしょうか。

また最近では、ポスドク募集のメールが多くなりました。 (図3)

Fig. 3.

\section{POSTDOCTORAL POSITION AVAILABLE}

Biochemistry of Pathogenic Fungi

TIGG University Medical College

Applications are sought for a post-doctoral position, to begin in the spring of 1998 (negotiable). The project involves purification and study of glycosyl transferases in pathogenic fungi, with the long term goals of both expanding basic science knowledge and identifying potential drug targets for treatment of medically relevant infections. Experience with biochemical purification of enzymes is essential; knowledge of glycobiology is desirable.

Stipend will be commensurate with experience, and subsidized housing in Osaka is available.

To apply, please send C.V. and names of references to:

Dr. Carbohydrate

Dept. of Pharmacology,

TIGG University Medical College

Suita 564-0062, Osaka Japan

fcca@gak.co.jp 
Both people hoping to recruit new fellows and those wishing to apply for positions can easily obtain news and information via TGN. Circulars of conferences and seminars are also contained in TGN mail.

As described above, the strong point of the TGN list is that it enables communication between unspecified people in the field. Indeed, this is the purpose of TGN. The benefits will increase as the Internet expands and the number of members multiplies.

\section{How to Submit Mail to the TGN Mailing List}

Mail for submission to the TGN list should be sent to tgn@vei.co.uk. Replies also should be sent to tgn@vei.co.uk in order to be read by all members of TGN, as described in Fig. 2. Of course, mail including private contents, for example an application for a postdoctoral position, can be sent directly to the sender.

\section{The WWW Home Page of TGN (http://www.vei.co.uk/ TGN/)}

If you access the WWW home page of TGN(Fig. 4) and click "About TGN" and "TGN Announcements", you can look at the activities of TGN. On "Information Resources", "Academic links" and "Commercial links", useful WWW sites related to carbohydrates can be accessed. In this section, we will mention the "Glycoscience Forum" and "EGC-3 (Virtual Conference Center)".

\section{D-1. Glycoscience Forum}

Mail from the TGN list is archived at the Glycoscience Forum. Recently, search facilities have become more powerful. You can search mail by subject, author, date and message
募集する側も応募する側も、多くの情報を短時間で手に入 れることができるようになったと言えます。その他、糖質関係 の学会やセミナーの扮知らせもたくさん送られてきます。

このように、糖質の研究にたずさわる不特定多数の人々に 向けてメッセージを発信し、それに対する反応を得られるとい うことが TGN の最大のメリットであり、また創設者の意とする ところでもあったと思われます。インターネットが世界をつな ぐ通信網として発展するほど、メーリングリストの登録者が増 えるほど、そのメリットは拡大していくことになります。

C. TGNメーリングリストにメールを出す

メールを書いて、tgn@vei.co.uk 宛に送るだけです。送られ てきたメールに対してコメントする場合は、上記メールのよう に(図2)なるべく tgn@vei.co.uk宛に送って、そのやりとり自身を 情報としてメンバーで共有することが TGN の精神に沿っている と言えます。もちろん、ポスドクの募集に対する問い合わせな どのような、個人的な内容の返事はこの限りではありません。

\section{TGNのホームページ(http://www.vei.co.uk/TGN/)}

TGNのホームページ (図 4 )にアクセスしてみれば、TGN の活動の全貌を見ることができます。“About TGN”や“TGN Announcements”などをクリックしてみましょう。また、左に並ん だ “Information Resources”や “Academic Links”、“Commercial Links”などには、糖質関係の便利なサイトがピックアップされ ています。ここでは、"Glycoscience Forum”と “EGC-3 (Virtual Conference Center)”について簡単にご紹介することにします。

\section{D-1. Glycoscience Forum}

基本的には、これまで TGN に送られてきたメールが保管さ れている場所です。最近になって検索機能が充実しました。夕 イトル、発信者、日付だけでなく、メール中の語句でも検索が 可能です。また、このページから TGN 宛のメールを出したり、

Fig. 4.

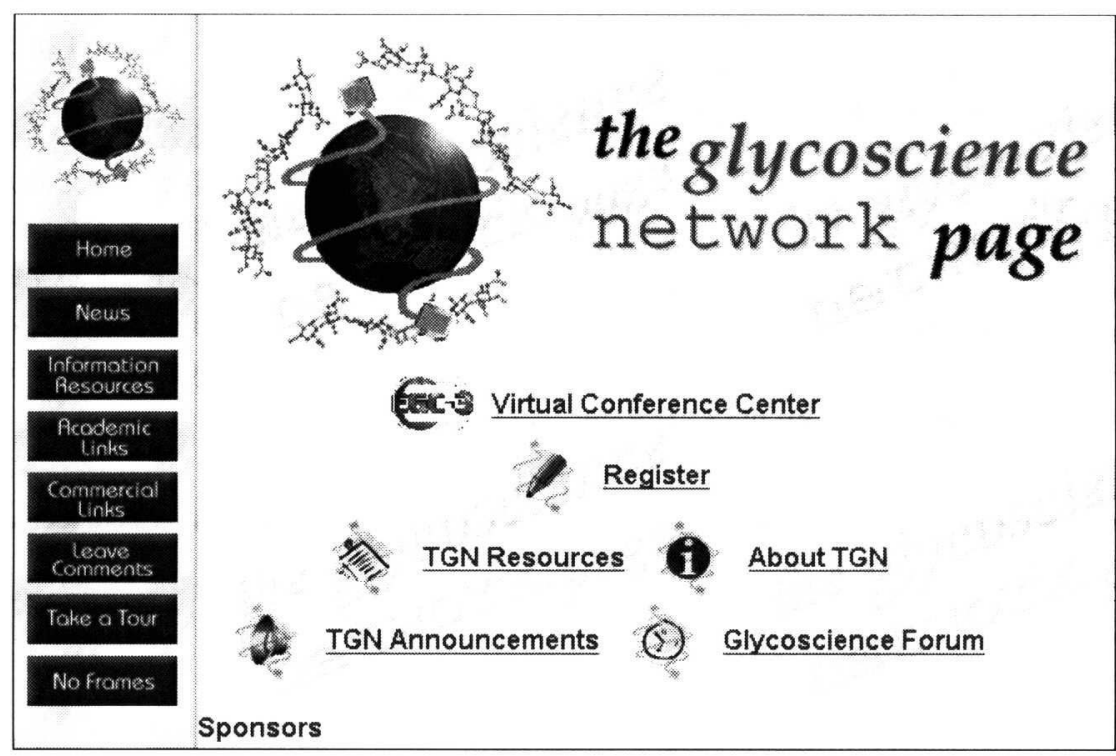


itself. Furthermore, you can also send messages and reply. The first time you log in you will be asked for your name and e-mail address.

\section{D-2. EGC-3 (Virtual Conference Center)}

EGC, which stands for The Electronic Glycoscience Conference, is a international meeting on glycoscience held on the Internet. The first conference was held in 1995, and the third one (EGC-3) took place from October 6th to 17th in 1997.

In the conference, all presentations are deposited at the conference FTP site and participants access them via the WWW. Real-time discussions take place by the live chat facilities according to the schedule. All the conversations can be read on the WWW page even after the discussion period, which is the merit of electronic conferences. It is necessary to pay for registration. When you access the conference site, you have to input your username and password.

Although the registration fee, which was 45 pounds (75 US dollars as of Oct. 1998) in EGC-3, is cheaper than the cost of traveling to attend a meeting held in a foreign country, electronic conferences cannot replace the traditional style conferences. They may share a role with electronic journals and mailing lists.

Finally, we hope that the progress of glycoscience will be greatly developed through unrestricted communication on the Internet.
過去のメールに対する返事を書いたりすることも簡単にできる ようになりました。このページにアクセスするときには、最初 に名前と e-mail アドレスを入力する必要があります。

\section{D-2 . EGC-3 (Virtual Conference Center)}

EGC は The Electronic Glycoscience Conference の略であり、 要するにインターネット上で開催される糖質科学の学会です。 1995 年に第1回目が開催され、第3回目(EGC-3)が昨年1997 年の 10月6日から17日に開催されました。

発表者は Virtual Conference Centerのサーバー上に自分のプ レゼンテーションのページを作成し、参加者がそれを自由に見 るというしくみです。ディスカッションの時間ももうけてあ り、いわゆるチャットによってリアルタイムで討論することが できます。さらにつけ加えると、その討論の様子を後で見るこ とができるというのが、このような形式の利点でしょう。これ に参加するには参加費を払う必要があり、ホームページにアク セスするときに名前とパスワードを入力することになります。

参加費は 45ポンド(日本円にして約1万円)でけっして安くは ありませんが、国際学会に出かけて行くことを考えれば非常に 経済的であると言えます。しかし、実際に一堂に会し、顔を合 わせながら会話する従来の学会にはそれなりのメリットがある と思われます。今後このようなインターネット上の学会が、い わゆる電子雑誌や、いつでも意見のやりとりができるメーリン グリストなどとどのように住み分けていくのかは興味深いとこ ろです。

最後に、このようなインターネット上でのオープンな情報 交換によって、糖質科学の分野がさらに発展をとげることを祈 ります。
An addendum to "How to Search Glycoconjugate Structures in the Complex Carbohydrate Structure Database (CCSD) with CarbBank on the Web Site" (TIGG, 10 (53), 257-271, 1998) by Nagai, Ken-ichi; and Ishizuka, Ineo.

Now the on-line site, where we can create and submit records to CarbBank, is available (http://128.192.9.29/ carbbank/CarbBank.htm). The carbohydrate sequence or structure published in your papers can be submitted to CarbBank, which contains a context-sensitive Help System, with specific examples, including entire structures, that can be 'copied' and 'pasted' into data entry fields. After you enter pertinent information (it takes only several minutes), submit the form simply by pushing the submission button. Submitted records are usually processed by the CarbBank staff within 24 hours.
GlycoNetシリーズ5月号の「複合糖質糖鎖構造データ ベース（CCSD）をCarbBank World Wide Webページで検 索してみよう」(永井謙一、石塚稲夫、TIGG, 10 (53), 257-271, 1998)への追加。「著者入力の勧め」。

CarbBankには画面 (http://128.192.9.29/carbbank/ CarbBank.htm)から簡単にレコードを入力でき(忙しい人は CarbBankに別刷りを送るだけでも)、世界の研究者の検索 の対象になります。構造はすでに入力されているものを コピーして来て一部を修正するだけで済むので、慣れれ ば僅か数分でひとつのレコードが完成します。詳細なへ ルプが用意されていますが、特に日本語での説明が必要 な方は著者(ii@med.teikyo-u.ac.jp) まで遠慮なくお問い合 わせ下さい。

石塚 稲夫 